7-1-1989

\title{
Die Konzeption einer Metaphysik im Denken von Heinrich Scholz, by Eberhard Stock
}

John E. Thiel

Fairfield University, jethiel@fairfield.edu

Follow this and additional works at: https://digitalcommons.fairfield.edu/religiousstudies-facultypubs (C) 1989 by University of Chicago Press.

\section{Peer Reviewed}

\section{Repository Citation}

Thiel, John E., "Die Konzeption einer Metaphysik im Denken von Heinrich Scholz, by Eberhard Stock" (1989). Religious Studies Faculty Publications. 49.

https://digitalcommons.fairfield.edu/religiousstudies-facultypubs/49

\section{Published Citation}

Thiel, John E. "Die Konzeption einer Metaphysik im Denken von Heinrich Scholz, by Eberhard Stock." Journal of Religion 69.3 (1989): 421-422.

This item has been accepted for inclusion in DigitalCommons@Fairfield by an authorized administrator of DigitalCommons@Fairfield. It is brought to you by DigitalCommons@Fairfield with permission from the rightsholder(s) and is protected by copyright and/or related rights. You are free to use this item in any way that is permitted by the copyright and related rights legislation that applies to your use. For other uses, you need to obtain permission from the rights-holder(s) directly, unless additional rights are indicated by a Creative Commons license in the record and/or on the work itself. For more information, please contact digitalcommons@fairfield.edu. 
these essays draw one quickly to the debated theological issues in recent American radical empiricism.

The bracing freshness of Loomer's proposals can best be experienced by first reading his essay with its combination of crisp reasoning and pathos in his recognition of the "emotional, psychic, and spiritual contradictions ... within a person" (p. 32) and "the unmanageable and efficacious undertows of existence" (p. 24). Loomer condemned theology's obsession with divine perfection. Perfection, he said, makes God a lifeless abstraction; God's concreteness is identification with the "struggling, imperfect, unfinished, and evolving" web of life (p. 41). The divine "size or stature" involves God in ambiguity because it is measured by "qualitative richness" (p. 43), "the transformation of incompatibilities and contradictions into compatible contrasts" (p. 51 ), and sustenance of relationship with the universe. Rejecting analogy and dipolarity, relationship implicates God in evil and ambiguity both ontologically and aesthetically but not morally.

His respondents want him to be clearer here than he can be on his principles. Lee and Brown think Loomer can make God personal consistently. If they are right, God is morally culpable, and a theodicy is required. With Axel, Frankenberry affirms Loomer's aversion to theodicy and his doubts about the theological enterprise itself (p. 84). In discussing Cobb, both the notion of a priori truth and that of an unchanging divine character are called in question (pp. $80,78)$. Yet radical empiricism does not require a "disabling" antithesis between empirical and rationalistic forms of thought. So Frankenberry is critical of this tendency in Loomer and in Dean's analysis of his development along these lines, as well as of Axel's rejection of systematic theology (pp. 78-79, 61).

Frankenberry is to be trusted in representing Loomer's perspective. "It was not clear [to Loomer] that there are any empirical grounds for an univocal assertion of divine goodness" (p. 84). If Loomer achieved size in his vision and achievement as a theological educator, there may be irony here. Still, the pathos in Loomer's theology resides in its call for exemplication of Godlike size by morally culpable beings in the name of a God who is not even perfect aesthetically.

EDGAR A. TOWNE, Christian Theological Seminary, Indianapolis.

\section{StOck, EberhaRd. Die Konzeption einer Metaphysik im Denken von Heinrich Scholz.}

Berlin: Walter de Gruyter, 1987. xx+246 pp. DM 98.00.

This monograph, an expanded 1985 Marburg University dissertation, addresses the issue of metaphysical foundations in the work of Heinrich Scholz (18841956). Scholz was a polymath who began his academic career with a 1909 dissertation on Schleiermacher's dogmatics. He turned his attention to the philosophy of religion near the time of his appointment at Kiel in 1919 and spent the $1920 \mathrm{~s}$ studying mathematics and theoretical physics, this latter change of direction setting the course for the rest of his career. In 1943 Scholz was appointed the first ordinary professor of mathematical logic and foundations (Grundlagenforschung) at Münster.

The remarkable variety in Scholz's talents and publications seems to raise doubts in Stock's mind about the possibility of writing a focused monograph, these unnecessary misgivings leading him to devote the first third of his book to the justification of a singular interpretation of Scholz's writings. Stock relies here perhaps too much on the rather slippery argument that the integrity of Scholz's 


\section{The Journal of Religion}

personality supports the coherence of his work and scholarly commentary thereon.

Stock centers his study on Scholz's major work, Metaphysik als strenge Wissenschaft (Köln, 1941). Drawing on Scholz's larger corpus to contextualize both the definition of metaphysics and search for legitimate foundations detailed in this book, Stock successfully expounds Scholz's efforts to elucidate the formal structures that ground any judgment of intellectual validity or truth. Much of Scholz's work, and so of Stock's commentary, takes up the semantic matter of how widely the term metaphysics applies. Scholz distinguished between "real" and "transcendental" philosophy and maintained that, too frequently in intellectual history, the former's speculative and, in his word, "confessional" content overshadowed the latter's necessary attention to the formal possibility of truth. Only the concerns of transcendental philosophy are legitimately wissenschaftich, a judgment that Scholz defends as a proper metaphysical preoccupation rather than as mere propaedeutic thereto. Scholz developed what might be described as a metaphysics of the analytical proposition that found its principal resource in Leibniz's logic of identity. Though critical of Scholz's appropriation of the Leibnizian notion of "possible worlds" to discuss the universal applicability of logical criteria, Stock is largely supportive of Scholz's attempt to mathematize the foundational dimension of metaphysics. He ably defends Scholz's special formulation of the conditions for legitimate acts of knowing and the logical criteria definitive of universal validity against the attacks of Scholz's contemporary critics: Kaila, Meschkowski, von Kempski, and Lang.

The book, unfortunately, disappoints the expectations one brings to a monograph published in a theological series. Stock traces Scholz's persistent interest in structures to his early preoccupation with Schleiermacher's insistence that only a formally correct dogmatics could be scientific. Though this is an important observation on his intellectual development, the theological matrix of Scholz's career is often implicity invoked as justification enough for theological interest Scholz's work. While Stock devotes the last ten pages of his book to a consideration of that work's theological implications, he ventures little more than the rather moralistic conclusion that theology would do well to take seriously Scholz's call for conceptual and, concomitantly, linguistic precision as it goes about its business.

JOHN E. THIEL, Fairfield University.

MCGill, Arthur C., Death and Life: An American Theology. Edited by Charles A. Wilson and Per M. Anderson. Philadelphia: Fortress Press, 1988. 109 pp.

For those of us who knew Arthur McGill well, this posthumous publication of his lectures on Death and Life is an important event. McGill did not publish much during his lifetime, so only a relatively small circle of students and colleagues have been able to benefit from his acute-if often quite idiosyncratictheological insights and observations. A master of the powerful image and the striking phrase, he made a deep impression on those who had the good fortune to hear him. McGill's virtuosity is vividly in evidence in the present book that brings together his reflections on what for him was a central theme of the Christian gospel: its highly distinctive and very dramatic reversal of our ordinary ideas about and attitudes toward death. McGill himself suffered from debilitating and 